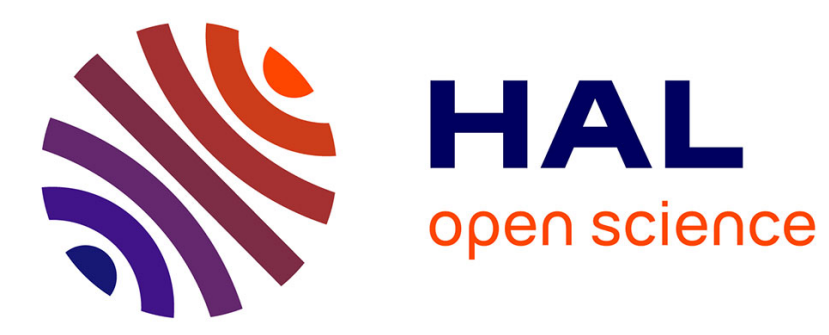

\title{
Nitrogen biogeochemistry of water-agro-food systems: the example of the Seine land-to-sea continuum
}

\author{
Gilles Billen, Josette Garnier
}

\section{To cite this version:}

Gilles Billen, Josette Garnier. Nitrogen biogeochemistry of water-agro-food systems: the example of the Seine land-to-sea continuum. Biogeochemistry, 2021, 10.1007/s10533-020-00739-7 . hal03181122

\section{HAL Id: hal-03181122 \\ https://hal.sorbonne-universite.fr/hal-03181122}

Submitted on 25 Mar 2021

HAL is a multi-disciplinary open access archive for the deposit and dissemination of scientific research documents, whether they are published or not. The documents may come from teaching and research institutions in France or abroad, or from public or private research centers.
L'archive ouverte pluridisciplinaire HAL, est destinée au dépôt et à la diffusion de documents scientifiques de niveau recherche, publiés ou non, émanant des établissements d'enseignement et de recherche français ou étrangers, des laboratoires publics ou privés. 


\title{
Biogeochemistry
}

https://doi.org/10.1007/s10533-020-00739-7

\section{Nitrogen biogeochemistry of water-agro-food systems. The example of the Seine land-to-sea continuum}

\author{
Gilles Billen ${ }^{1}$ and Josette Garnier ${ }^{1}$ \\ ${ }^{1}$ Sorbonne-Université, CNRS, EPHE, UMR METIS 7619, Paris (France).
}

\begin{abstract}
As an illustration of the usefulness of the concept of water-agro-food systems, this paper describes the mechanisms behind the nitrogen cascade from agricultural soils to the coastal sea rivers through aquifers, riparian wetlands, rivers and streams and the estuary, for the case study of the Seine river watershed and its receiving coastal sea. It is stressed that the structure of the agro-food system, i.e. the way food production and trade, as well as consumption and waste management are organized, is the main determinant of the quality of ground- and surface water as well as of aquatic ecosystem functioning.
\end{abstract}

\section{Key words}

Nitrogen cascade, agro-food system, Seine River, denitrification, eutrophication, leaching, nitrous oxide emission.

\section{Introduction}

Nitrogen $(\mathrm{N})$, an essential nutrient in the composition of living organisms, present in proteins and nucleic acids, and also one of the major limiting factors of primary production in terrestrial as well as in aquatic systems, has long been known to play a central role in the control of ecosystem functioning. The massive introduction of reactive nitrogen in the biosphere by human activity since the discovery of the Haber-Bosch process completely changed this control, especially since the 1950s with the intensification and modernization of agriculture to feed the increasing population (Smil, 1999; Galloway et al., 2004; Gruber \& Galloway, 2008). As early as 1924, Lotka already saw that the development of the nitrogen fertilizer industry represented "nothing less than the ushering in of a new era in the history of the human race, a new cosmic epoch. In the short span of a dozen years -geologically speaking in an instant- man has initiated transformations literally comparable in magnitude with cosmic processes" (Lotka, 1924). Since then, the multiple environmental and societal threats created by this excessive anthropogenic introduction of reactive nitrogen ( $\mathrm{Nr}$ ) into the biospheric cycle have been underlined, at local, regional and global scales. It affects air quality and greenhouse gas balance, soil quality through acidification, and water quality through nitrate contamination and eutrophication, as well as contributing to biodiversity losses (Sutton et al., 2011).

This paradigm of the nitrogen cascade (Galloway et al., 2003) can be combined with the vision that close links exist between the biogeochemical functioning of aquatic and terrestrial systems, as well between the diverse aquatic ecosystems succeeding each other along the upstream downstream gradient of complex drainage networks. This land-to-sea continuum 
view extends the river continuum concept formulated by several authors in the 1980s (Vannote et al., 1980; Ward, 1989), but places a special emphasis on the relationship with terrestrial ecosystems, hence on the importance of land cover and land use of the watershed as determinants of the biogeochemistry of rivers and streams including their discontinuities such as reservoirs, estuaries and coastal seas. This view embraces the full land sea continuum, from terrestrial to marine systems.

Another paradigm that was developed during the past decade states that food production can be considered the first determinant of land cover and land use changes, not only through agricultural practices, but also through the structure of the whole system by which food is produced to meet the dietary requirements of the population (see among other studies, the EAT-Lancet Report, Willet et al., 2019). This implies that agro-food systems should be considered as an integral part of hydrosystems for a full understanding of the interactions between human activity and water quality. This is exactly the idea behind the concept of water-agro-food systems as formulated by Garnier et al. (2015, 2019a).

The purpose of this article is to present the integrated vision we developed of the socioecological metabolism of the Seine watershed territory through the prism of nitrogen transformations and transfers from land to sea, from a long term perspective. We first set the stage by presenting the basic physical geographic features of the Seine basin and the long term trajectory of the agro-food system itself. We then follow the journey of nitrogen from its introduction as a limiting nutrient in cropping systems to its losses to the hydrosphere (via leaching essentially in the form of nitrate, $\mathrm{NO}_{3}{ }^{-}$), or to the atmosphere (via emissions of dinitrogen, $\mathrm{N}_{2}$ ) or nitrous oxide, $\mathrm{N}_{2} \mathrm{O}$ ). We also focus on the fate of leached nitrogen through aquifers and riparian zones down to rivers, where it is joined by nitrogen originating from human excretion in urban areas, before being delivered to the sea. The issue of resulting marine eutrophication in the Seine Bay complements the integrative vision. Two contrasting scenarios of what the nitrogen cycle in this land sea continuum could look like in the next 30 50 years are finally presented.

\section{The Seine watershed, its river network and the Seine Bay}

The Seine watershed occupies the middle of the large Paris Basin, a sedimentary concentric rock formation, with tertiary limestone at the center, followed by a large cretaceous chalk area separated by a narrow clay band from Jurassic limestones at the periphery. These rock layers, often compared to a pile of plates, lie on an ancient massif of metamorphic and igneous rocks outcropping at the extreme north-east and south-east (Fig. 1a). The Seine River system, with a total watershed area of approximately $75000 \mathrm{~km}^{2}$, drains these geological layers via a regular network of tributaries converging to the large fluvial lower Seine River at the beginning of which Paris lies, $350 \mathrm{~km}$ from the outlet to the sea. In the second half of the $19^{\text {th }}$ century, sluice-locks were installed on the lower Seine and its main tributaries for navigation development. The macrotidal estuarine part of the river begins at Poses, where the last of these dams is located. The estuary has also been largely managed for the purpose of navigation and harbor activities. The Seine estuary delivers its water into the Seine Bight, a rather shallow (25 m mean depth) $3775 \mathrm{~km}^{2}$ open bay in the English Channel.

Land use currently comprises $50 \%$ cropland, $10 \%$ permanent grassland, $0.7 \%$ vineyard and orchard, $26 \%$ forest and $11 \%$ urban and artificialized areas (Fig. 1b). The current population is 17.5 million inhabitants, mostly concentrated in the huge Paris agglomeration and along the lower Seine River sector down to the harbors of Rouen and Le Havre (Fig 1c). The most upstream areas have a declining population. 


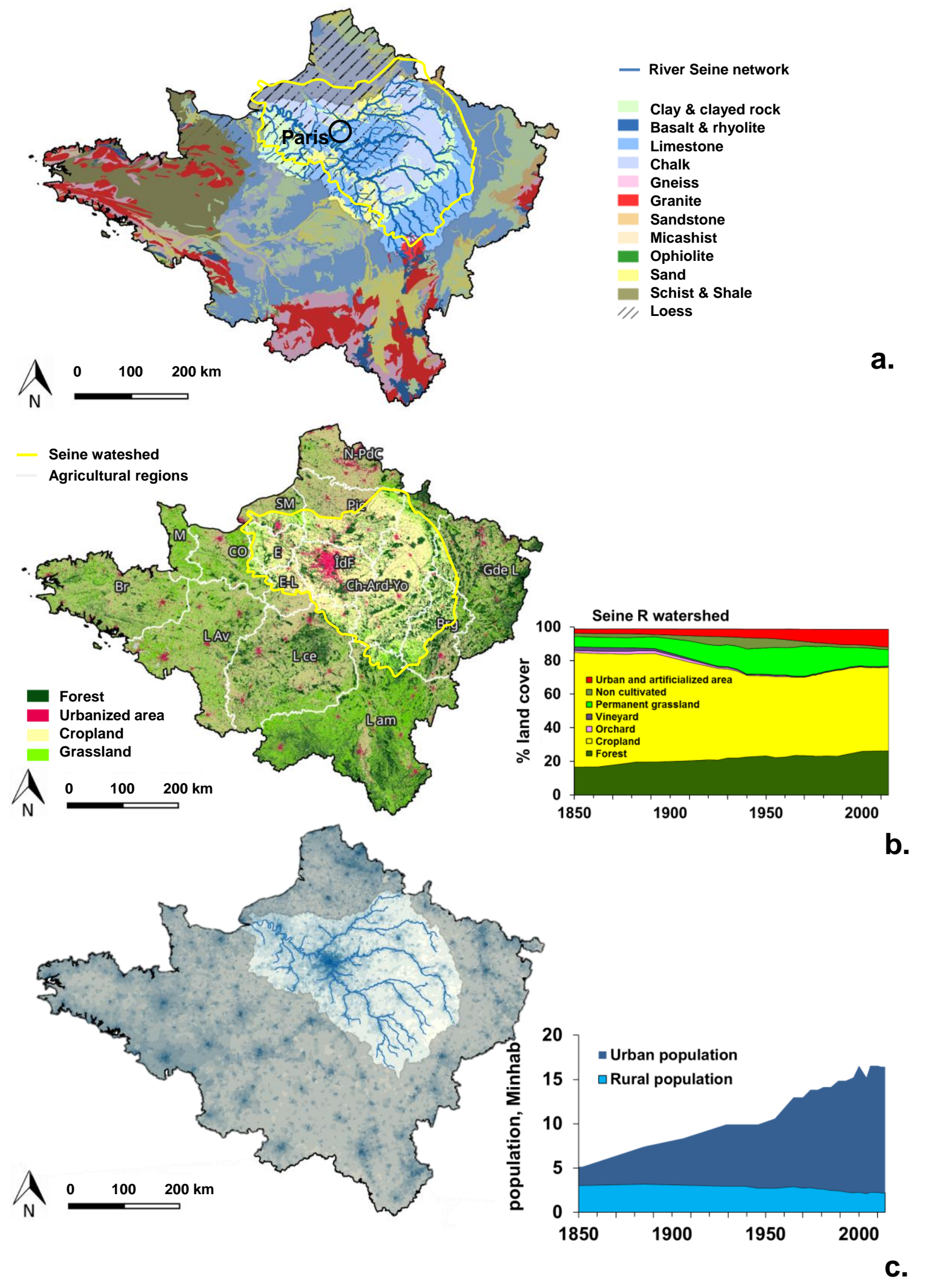

Figure 1. a. The Seine River system and the geological formations of its watershed and surrounding areas (source: BRGM www.brgm.fr). From left to right b. Current distribution of land use (source: Corine Land Cover 2012, www.data.gouv.fr/fr/datasets/corine-land-cover-occupation-des-sols-enfrance) and land cover variations in the Seine watershed since 1850 (data from Le Noë et al. subm) c. Current distribution of population density (INSEE 2017 https://www.insee.fr/fr/information/2008354.) and population evolution in the Seine watershed (data from Le Noë et al., 2018) 


\section{Long-term trajectory of the agro-food system}

In the second half of the $19^{\text {th }}$ century, like in most regions under temperate climate, the dominant agricultural system in the Seine watershed and in the surrounding regions was based on mixed crop and livestock farming, with crop rotations alternating between one year of forage legume and two years of cereals, and livestock manure being the major fertilizer input in addition to symbiotic fixation of atmospheric nitrogen by legumes (Fig. 2a). This system was able to sustain a rural population of approximately 50 inhabitants per $\mathrm{km}^{2}$, based on a diet of $5 \mathrm{kgN} / \mathrm{cap} / \mathrm{yr}$ with one-third animal proteins, and to still export enough surplus to feed the large Paris agglomeration (Billen et al., 2012a,b, 2019; data from Le Noë et al., 2018). Gradually during the first half of the $20^{\text {th }}$ century, and then rapidly during the three decades following World War II, the region in the center of the Paris Basin specialized into stockless crop farming, replacing symbiotic fixation and manure by synthetic fertilizers as the main $\mathrm{N}$ inputs to arable soils. Livestock was concentrated in peripheral regions, in the eastern part of the basin (remaining in mixed crop and livestock farming system, Mignolet et al., 2007), and in the "Great-West" (where intensive livestock farming developed, highly dependent on forage import, particularly soybean grain and cakes from South America, Fig. 2b).

These trends in territorial specialization of farming systems went hand in hand with a commercial opening of agriculture. Today, the Seine basin area exports $80 \%$ of its cereal production, while it imports $70 \%$ of the animal proteins consumed by the population (Fig. 2). The share of animal-to-total protein intake in the human diet, was about $30 \%$ at the end of the $19^{\text {th }}$ century, a proportion consistent with the ratio of animal to vegetal proteins produced by the mixed crop and livestock farming system. Animal protein intake has increased considerably in proportion, reaching $70 \%$ of the total protein ingestion in the beginning of the 21 st century, and has slowly decreased in recent years (Le Noë et al., 2018). Human excreta in the $19^{\text {th }}$ century was considered a useful fertilizing resource, collected in cesspools, and then through sewer networks (Barles, 2005; Esculier \& Barles, 2019). It is currently treated in wastewater purification plants, which eliminate about $57 \%$ of $\mathrm{N}$ in excreta as atmospheric dinitrogen through an energetically expensive process of denitrification (using methanol as an electron donor), recover $4 \%$ as sludge, only a small part of which is recycled in agriculture, and discharge the remaining part (39\%) to surface water (Esculier et al., 2018). The circularity of human excreta management, i.e. the proportion of $\mathrm{N}$ in human excreta that is returned to agricultural land, peaked in the 1900's to approximately $40 \%$, and decreased since then to a negligible amount.
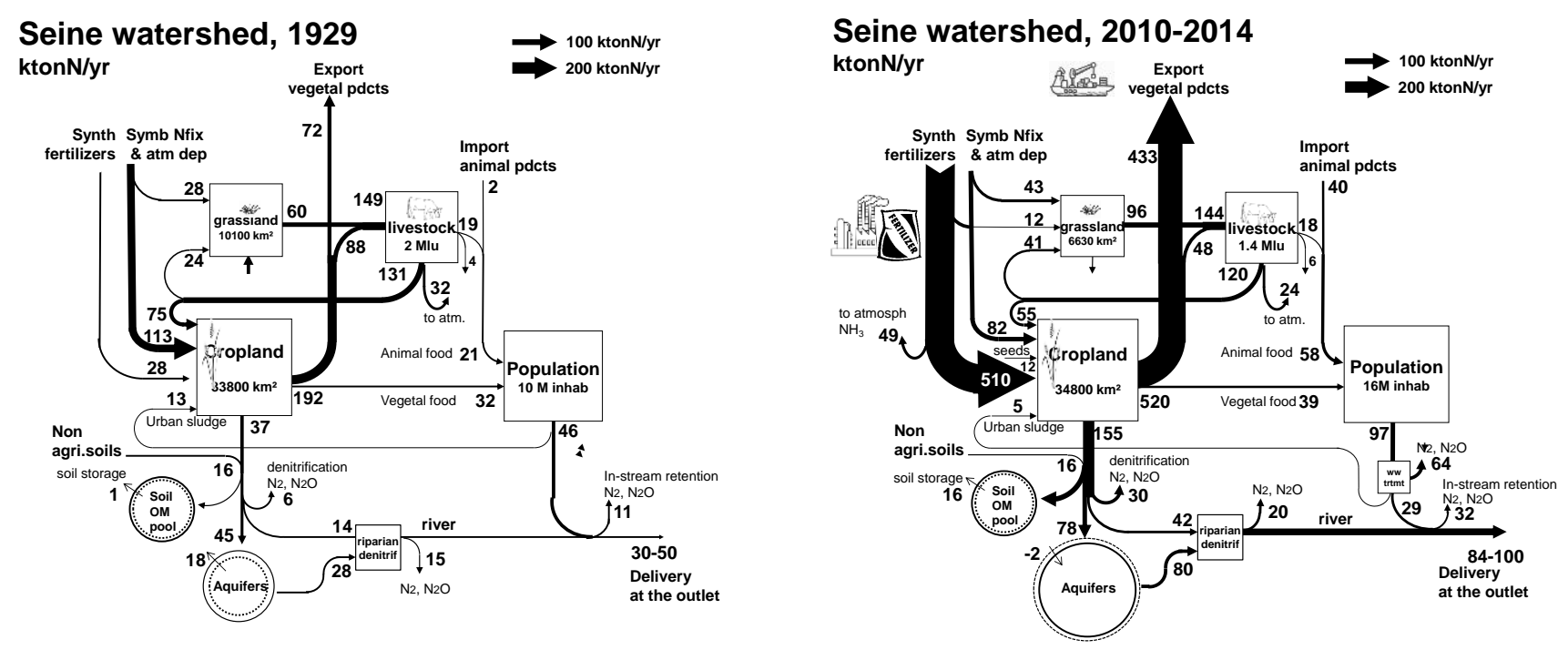

Figure 2. GRAFS representation of the agro-food system of the Seine watershed in the periods of 1929 and 2010-2014 (data from Le Noë et al., 2017, 2018). 


\section{The consequences of intensification of cropping systems}

The trend described above toward territorial specialization of agriculture developed alongside the simplification of crop rotations and intensification of soil $\mathrm{N}$ inputs. Crop rotations alternating between forage legumes, wheat and oats, which dominated in the central region of the Paris Basin until the early 1950s, were gradually replaced by rotations alternating between rapeseed, wheat, and barley or grain maize.

Lassaletta et al. (2014) have shown that a robust relationship exists, for a given pedoclimatic context, between yield ( $\mathrm{Y}$ in $\mathrm{kgN} / \mathrm{ha} / \mathrm{yr}$, expressed in terms of $\mathrm{N}$ content of harvested products over the whole crop rotation cycle) and total $N$ inputs to soil ( $F$ in $\mathrm{kgN} / \mathrm{ha} / \mathrm{yr}$, including manure, symbiotic fixation, atmospheric deposition and synthetic fertilizers over the rotation cycle). This relationship can be represented by a single parameter hyperbolic function of the form: $Y=Y \max F /(F+Y \max )$, where Ymax characterizes the fertility of the cropping system at maximum $\mathrm{N}$ availability, in a given pedo-climatic context. The data gathered from the reconstituted chronicles of crop production and fertilization in the different agricultural regions of the Seine basin over the period 1950-2015 (data from Le Noë et al., 2018) show a trajectory that describes such a relationship, with a relatively constant Ymax, although a trend toward a slightly higher Ymax value (i.e. higher yields at similar or even lower rate of $\mathrm{N}$ inputs) is observed after the 1980's (Fig. 3). A similar relationship holds for individual crop rotations in each regions of the Seine basin documented by agronomical surveys for both conventional and organic rotations (Anglade et al., 2015a,b; Rakotovololona et al., 2018). Interestingly, the same relationship describes both systems, indicating that there is no intrinsic fertility gap inherent to organic farming practices.
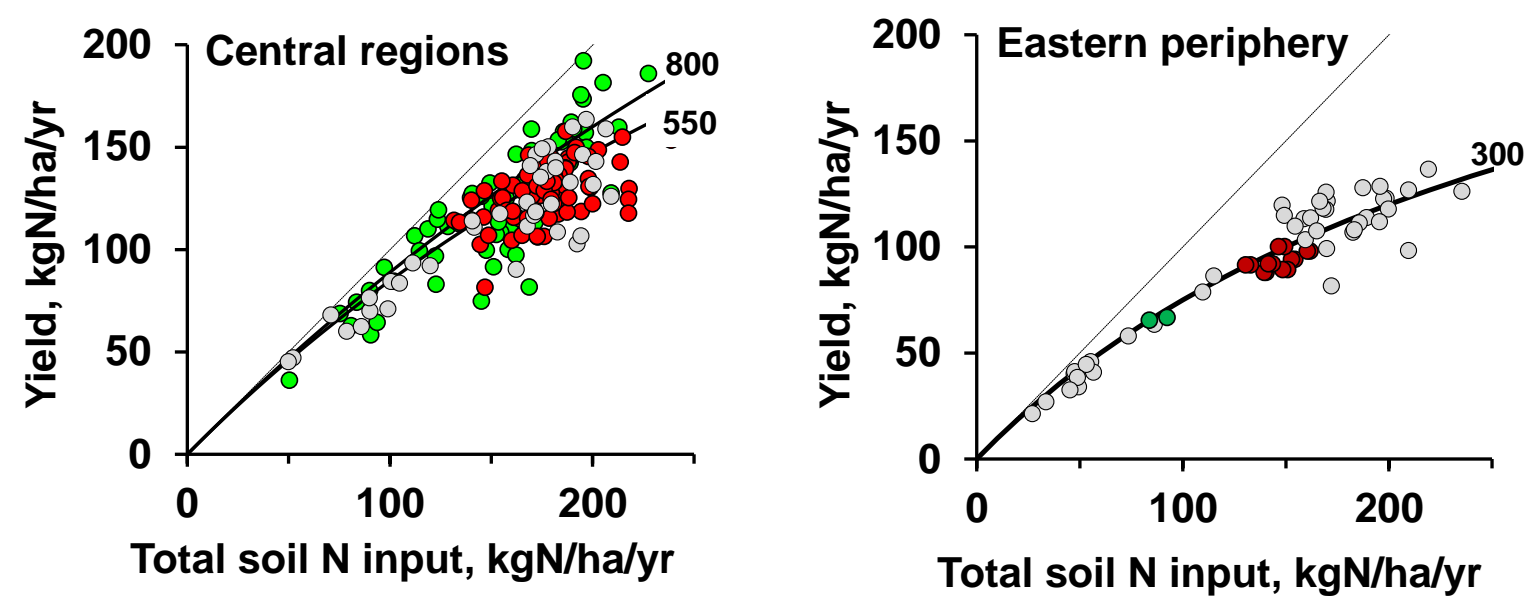

a.

b.

Figure 3. Yield-fertilization relationships for crop rotations in the central regions of the Paris Basin (a) and in the regions of the eastern periphery of the Seine watershed (b). The ordinate is the annual average export of $N$ imbedded in crop harvest exported over the complete rotation cycle; the abscissa is the annual average $N$ input to the soil as manure, symbiotic fixation, atmospheric deposition and synthetic fertilizer. Gray circles refer to the reconstituted chronicles of the cropping system of lle-deFrance and Picardy (a) and Bourgogne and Lorraine (b) (Le Noë et al., 2018); red and green circles refer to data from current individual crop rotations in conventional (red) and organic (green) farming systems (Anglade et al., 2015b; Rakotovololona et al, 2018). The black curves show the theoretical $Y$ vs F relationship for the stated values of Ymax (in $\mathrm{kgN} / \mathrm{ha} / \mathrm{yr}$ ).

Yield-N input relationships are useful, as they allow us to predict the environmental losses of $\mathrm{N}$ resulting from agricultural practices. The shape of the relationship implies that these losses - defined as the $\mathrm{N}$-surplus, i.e. the difference between $\mathrm{N}$ inputs and yield - increases with 
intensification, i.e. with increasing fertilization. In other words, nitrogen use efficiency (NUE: the ratio of $\mathrm{N}$ yield over $\mathrm{N}$ total input) decreases with increasing fertilization. The agricultural $\mathrm{N}$-surplus for cropland of the Seine watershed thus increased from close to $6 \mathrm{kgN} / \mathrm{ha} / \mathrm{yr}$ in 1850 to as much as $85 \mathrm{kgN} / \mathrm{ha} / \mathrm{yr}$ at the end of the $1980 \mathrm{~s}$, after which it slightly decreased to approximately $50 \mathrm{kgN} / \mathrm{ha} / \mathrm{yr}$ in 2015 (Fig. 4).

The fate of the surplus, if not stored in the soil organic matter (OM) pool, is either to be lost to the atmosphere or to the hydrosphere. In cropland, leaching generally represents by far the largest fraction of the surplus, unless cover crops are systematically implemented in order to avoid bare soils during the wet autumn and winter season (Constantin et al 2010; Justes et al, 2012), a practice that also increases soil OM storage (Autret et al., 2016, 2019).

Le Noë et al. $(2019 a, b)$ estimated the long term dynamics of organic carbon (C) in the arable soils of France. Sequestration was shown to be mainly the result of soil inputs of humified crop residues, and only secondarily of manure application. In the Seine basin, low rates of sequestration, or even negative rates (i.e. net mineralization) were observed at the beginning of the $20^{\text {th }}$ century. During the 30 years following World War II, which was marked by a rapid increase in crop productivity, higher rates of $C$ sequestration occurred, which levelled off from the end of the 1980's. As the C:N ratio of soil OM is rather constant at around a value of $10 \mathrm{gC} / \mathrm{gN}$ (Benoit et al., 2016, Le Noë et al., 2019b), much lower than the C:N ratio of crop residues, the corresponding $N$ sequestration in soil OM can be easily calculated (Fig. 4). As a mean for the arable land of the Seine watershed, it varied from $18 \mathrm{kgN} / \mathrm{ha} / \mathrm{yr}$ in the 1970's to approximately $5 \mathrm{kgN} / \mathrm{ha} / \mathrm{yr}$ in the $2010 \mathrm{~s}$.

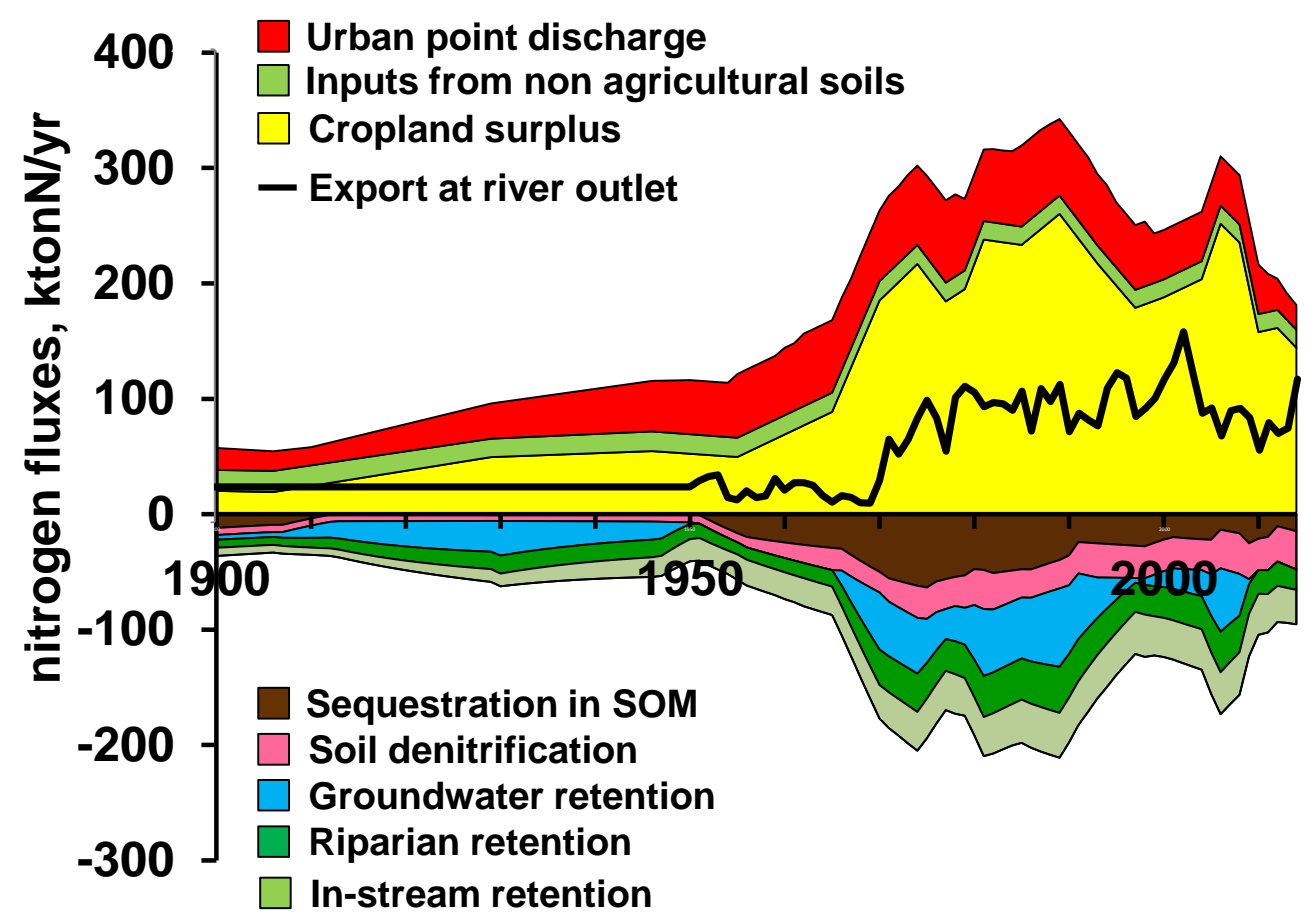

Figure 4. Nitrogen budget of the Seine river watershed (limited at Poses, $69000 \mathrm{~km}^{2}$ ). Positive fluxes are the inputs to the water system:(1) cropland $N$ surplus defined as the share of $N$ soil inputs that is not exported by crop harvest; (2) $N$ inputs to the hydrosystem from non-cropland soils (3) urban wastewater discharge to the river system after treatment. Negative fluxes refer to "retention" processes: (1) N sequestration in the soil organic matter pool, (2) soil denitrification; (3) temporary retention in vadose zone and aquifer; (4) riparian denitrification and (5) in-stream denitrification. The black curve refers to the river $N$ delivery at the outlet of the river network: it roughly corresponds to the difference between inputs and retentions. 
Another fraction of the surplus is eliminated to the atmosphere through soil denitrification, the process of anaerobic respiration of $\mathrm{OM}$ using nitrate as an electron acceptor, occurring in anoxic micro-zones of the soil. Wet conditions, high soil content of nitrate and OM are conditions triggering soil denitrification (Tiedje et al., 1982; Knowles, 1982; Weier et al., 1993). Although dinitrogen is the main end product of denitrification, nitrous oxide, a potent greenhouse gas, is also produced (Vilain et al., 2014; Benoit et al., 2014). For soil denitrification, $\mathrm{N}_{2} \mathrm{O} /\left(\mathrm{N}_{2}+\mathrm{N}_{2} \mathrm{O}\right)$ ratios in the range of 16-40 (median 28) have been estimated (Box 1). Soil $\mathrm{N}_{2} \mathrm{O}$ emission, although of episodic nature, is widely measured using static chambers. Garnier et al. (2019b) have proposed an empirical relationship relating soil $\mathrm{N}_{2} \mathrm{O}$ emissions (hence soil denitrification) to climatic data and fertilization rates. Using this relationship, soil $\mathrm{N}_{2} \mathrm{O}$ emission, as well as denitrification, in the Seine watershed was estimated for the period 1900-2015 (Fig. 4). Current values of soil denitrification range at approximately $15-20 \mathrm{kgN} / \mathrm{ha} / \mathrm{yr}$.

On an annual basis, leaching is the difference between surplus, $\mathrm{N}$ storage in soil $\mathrm{OM}$ and denitrification (Billen et al., 2019b). Calculations of the leaching from the surplus minus denitrification and sequestration (Fig. 4), well agrees with on-field measurements, using suction cups, which amounted to $16.2 \pm 6.3 \mathrm{~kg} \mathrm{~N} \mathrm{ha}^{-1} \mathrm{yr}^{-1}$ (Benoit et al., 2016). 


\section{Box 1: $\mathrm{N}_{2} \mathrm{O} /\left(\mathrm{N}_{2}+\mathrm{N}_{2} \mathrm{O}\right)$ ratio of denitrification in soils and aquatic systems.}

Considerable disagreement exists in the literature concerning the relative share of $\mathrm{N}_{2}$ and $\mathrm{N}_{2} \mathrm{O}$ in the final products of denitrification under environmental conditions. Yet, this issue is of considerable practical importance for two reasons. First because $\mathrm{N}_{2} \mathrm{O}$ is a potent greenhouse gas so that the use of denitrification as a way to eliminate nitrate from seepage or wastewater is potentially harmful for the climate, second, because as $\mathrm{N}_{2} \mathrm{O}$ emission is more easy to measure than $\mathrm{N}_{2}$ production, the former is often used as an indirect way to evaluate the latter.

Many authors report the $\mathrm{N}_{2} \mathrm{O} /\left(\mathrm{N}_{2}+\mathrm{N}_{2} \mathrm{O}\right)$ ratio by denitrification under laboratory conditions where several factors, such as $\mathrm{pH}$, nitrate, oxygen or organic matter concentration are manipulated (e.g. Rochester, 2003; Hénault et al., 2005, 2020). The observed effect of these factors may simply reflect the transient perturbation linked to an enzymatic or population readjustment to new conditions imposed by the experimental protocol (Simek et al., 2002a,b). On the other hand, many so called 'in situ' determinations used the acetylene block technique, based on the assumption that acetylene selectively inhibits the last step of denitrification, leaving $\mathrm{N}_{2} \mathrm{O}$ as the sole end product. ButterbachBahl et al. (2013) have convincingly demonstrated that this assumption is incorrect and that the presence of acetylene modifies other microbial processes, leading to a severe overestimation of the $\mathrm{N}_{2} \mathrm{O} /\left(\mathrm{N}_{2}+\mathrm{N}_{2} \mathrm{O}\right)$ ratio.

Leaving aside the values obtained with these debatable procedures, we are left with only a few direct determinations of the $\mathrm{N}_{2} \mathrm{O} /\left(\mathrm{N}_{2}+\mathrm{N}_{2} \mathrm{O}\right)$ ratio which however show a consistent trend toward one order of magnitude higher ratios in soils (either agricultural or natural) than in wetlands or water bodies (Table B1). The different contribution of nitrification to $\mathrm{N}_{2} \mathrm{O}$ emission beside denitrification can be an explanation for this observation. This also applies to the high $\mathrm{N}_{2} \mathrm{O}$ emission ratio by wastewater treatment facilities. The values in Table $\mathrm{B} 1$ have been used in this study to calculate $\mathrm{N}_{2} \mathrm{O}$ emissions from estimated denitrification in river and riparian wetlands and to calculate denitrification from estimated $\mathrm{N}_{2} \mathrm{O}$ emissions from agricultural and forested soils.

Table B1: In situ determination of the $\mathrm{N}_{2} \mathrm{O} /\left(\mathrm{N}_{2}+\mathrm{N}_{2} \mathrm{O}\right)$ ratio in soils, wetlands and water bodies, excluding those obtained using the acetylene block technique.

\begin{tabular}{|c|c|c|c|}
\hline Environment & $\mathrm{N}_{2} \mathrm{O} /\left(\mathrm{N}_{2}+\mathrm{N}_{2} \mathrm{O}\right)$ ratio, \% & $\mathrm{nb}$ measurements & reference \\
\hline Agricultural soils & $28 \pm 12$ & 30 & Schlesinger, 2009 \\
\hline Natural soils & $28 \pm 17$ & 18 & $\begin{array}{l}\text { Butterbach-Bahl et al, } 2013 \text { * } \\
\text { ibid }\end{array}$ \\
\hline Wetlands, flooded soils & $4 \pm 5$ & 14 & ibid \\
\hline Rivers & $0.9 \pm 0.4$ & 40 & Beaulieu et al., 2011 \\
\hline Rivers and riparian zones & $1.5 \pm 0.5$ & 3 & Billen et al, 2020 \\
\hline Wastewater trtmt facilities ${ }^{* *}$ & $17 \pm 10$ & 15 & Kampschreur et al., 2009 \\
\hline
\end{tabular}




\section{Nitrogen in the hydrosystem}

Nitrate leaching is the main process by which nitrate originating from soil processes is transferred to the hydrosystem. As a first approach, nitrate concentration in the total specific runoff water flux (i.e. precipitation minus evapotranspiration, expressed in $\mathrm{mm} / \mathrm{yr}$ ) over a cropland area can be estimated from the $\mathrm{N}$ soil surplus minus denitrification and $\mathrm{N}$ sequestration, divided by the total runoff over the same area. A part of the corresponding water flux, which we assume has the same nitrate concentration, rapidly joins surface water (surface or sub-surface rapid runoff), another part infiltrates the vadose zone and the underlying aquifer (aquifer recharge). On a pluri-annual time scale, this partition is termed the base-flow index, the ratio of groundwater (slow) to total (slow and rapid) runoff in the river annual discharge. The presence of large aquifer formations, particularly in the center of the Seine watershed, confers a rather large value to the base-flow index, varying between 0.36 and 0.85 according to the geological substratum (Gallois, pers. comm.), with an average value around 0.70 . While rapid runoff reacts rapidly to changes in agricultural practices, base flow responds much more slowly, depending on the time required for groundwater composition to reach equilibrium with the composition of recharge water (Fig. 5). This delay, which varies according to the specific characteristics of the vadose zone and aquifers in the different areas of the watershed, leads to a transient retention of nitrate, which was modelled by Ledoux et al. (2007) and Beaudoin et al. (2016) (Fig. 4). Figure 5 illustrates this response by comparing the reconstituted time variations of nitrate concentration in the recharge water with the observed concentration in a number of well-documented springs in the central part of the Paris Basin. The mean nitrate concentration in the recharge water (CrNO3, $\mathrm{mgN} / \mathrm{l})$ of the central Paris Basin (Ile-de-France region) was calculated for the period 1850-2015 from the following relationship:

CrNO3 $=$ Crforest ${ }^{*}(1$-frcropld $)+\left[(\text { Surpl-Denit-Nsequ })^{*} 10^{9} /\right.$ Acropld $] /\left(\right.$ Runoff $\left.{ }^{*} 10\right){ }^{*}$ frcropld

where:

Crforest is the nitrate concentration in leaching water from forest and unmanaged grassland; it has been estimated at approximately $0.5-2 \mathrm{mgN} / \mathrm{l}$ from observations of the drainage concentration of natural areas in the Seine basin (Billen et al., 2007b),

frcropld is the fraction of land area occupied by cropland, which varies over the long term;

Surpl and Acroplnd are, respectively, the calculated $\mathrm{N}$ soil surplus of arable land in the considered territory expressed in ktonN/yr, and the area of cropland in ha, as estimated by Le Noë et al. (2018);

Denit is the cropland soil denitrification rate in ktonN/yr estimated from the $\mathrm{N}_{2} \mathrm{O}$ emission calculated by Garnier et al. (2019b) taking into account an $\mathrm{N}_{2} \mathrm{O} /\left(\mathrm{N}_{2} \mathrm{O}+\mathrm{N}_{2}\right)$ ratio of 28 (Box 1); Nsequ is the $\mathrm{N}$ sequestration in the soil OM pool of cropland, in ktonN/yr, estimated from the C sequestration rate calculated over the long term by Le Noë et al. (2019b), considering a constant $\mathrm{C} / \mathrm{N}$ ratio of $10 \mathrm{gN} / \mathrm{gC}$ (see above);

Runoff is the mean long term value of total runoff over the considered area, estimated to be $260 \mathrm{~mm} / \mathrm{yr}$, for the whole watershed $\left(63000 \mathrm{~km}^{2}\right.$ at Poses), based on the long term record of discharge of the Seine river at the outlet (Poses, $512 \mathrm{~m}^{3} / \mathrm{s}$ in average over the last $50 \mathrm{yrs}$ ).

It can be seen that the delay in the response of aquifers to the increase in nitrate concentration of recharge water is typically of approximately 10-25 years (Fig. 5). This is in good agreement with determinations of groundwater age using measurements of dissolved chloro-fluoro-carbon compounds (Vergnaud-Ayraud, et al., 2008) in several drinking water wells in the Seine basin (Anglade et al., 2017; Beaudoin et al., pers. comm.). 


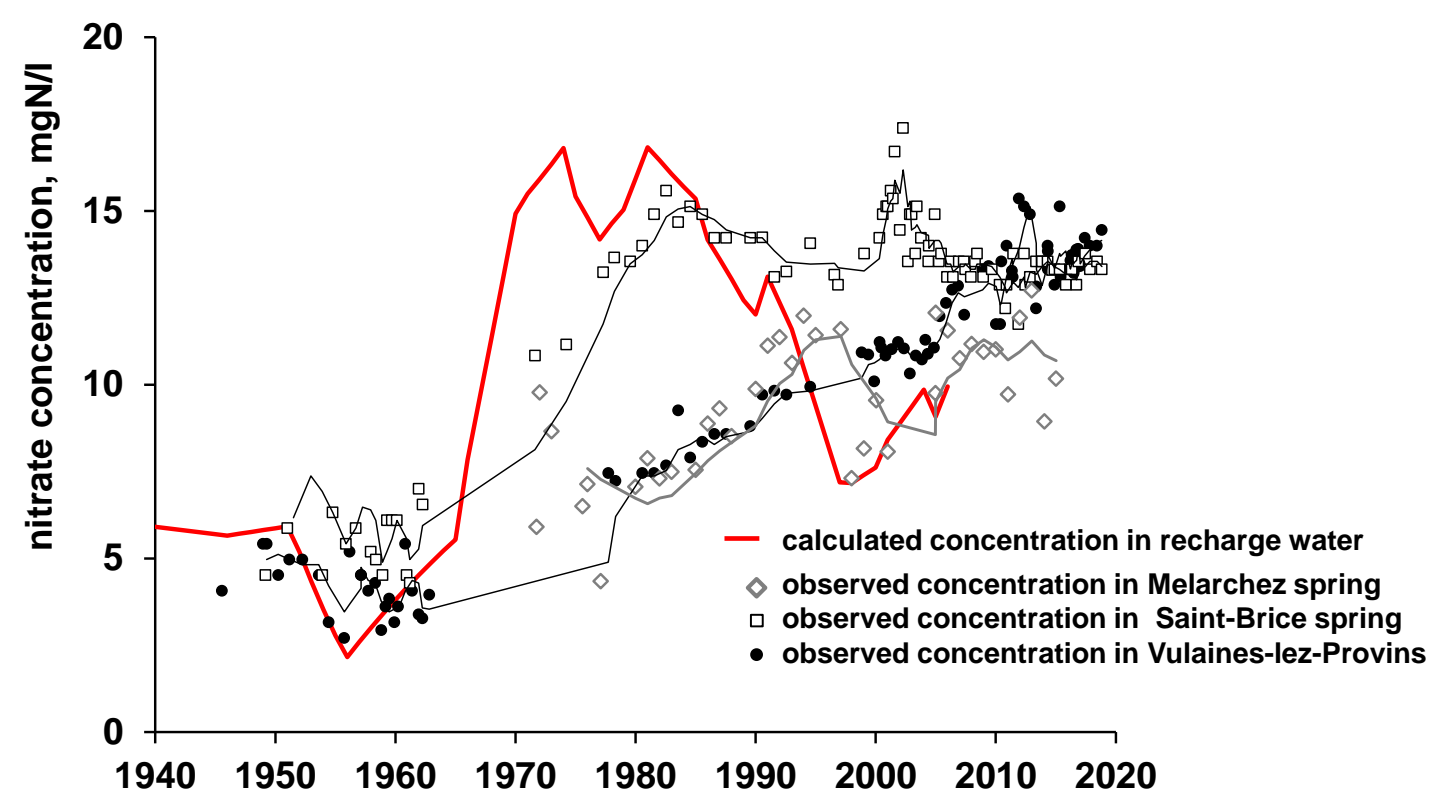

Figure 5. Long term trends in groundwater nitrate concentrations from data on several individual springs in the central Seine Basin (Vulaines-lez-Provins and Saint Brice, Aquibrie, pers. comm.; Melarchez, Anglade et al., 2017) with varying residence time, compared with the calculated concentration of recharge water in lle-de-France, calculated by relation (1).

Both base flow and surface runoff, with their own differing composition, have to cross the riparian zone before reaching surface water, unless it has been by-passed by the installation of tile drains, a widespread practice in some regions of the Seine basin until the 1980s and is still the case for almost $11 \%$ of the Seine watershed area. The riparian zone generally consists of a more-or-less wide area of uncultivated wetlands, where ground- and subsurface waters flowing from the watershed reach the upper, biogeochemically active layer of the soil (Fig. 6). The soil denitrification potential is expressed there by its capacity to reduce the nitrate loading of the water flow, before it reaches the river itself. Based on this conceptual scheme and on a basin-wide delimitation of riparian zones resting on land use and on topographic indexes (Berthier et al., 2014), Billen et al. (2018b, 2020) modeled nitrate and $\mathrm{N}_{2} \mathrm{O}$ dynamics associated with these riparian processes (Fig. 6), and provided an estimate of their significance at the local and basin scales (Fig. 4). These data show that although riparian areas are hotspots of denitrification and $\mathrm{N}_{2} \mathrm{O}$ emission in the sense that per area flux values are generally higher there than at other sites in the watershed, the integrated value at the watershed scale is lower, because of the small proportion of watershed area covered by active riparian wetlands (see Garnier et al., 2014). Riparian denitrification currently amounts about $15 \%$ of the diffuse flux of nitrogen at the watershed scale. This figure could have been twice higher in earlier times, before riparian wetlands were drained and/or converted to cropland. 


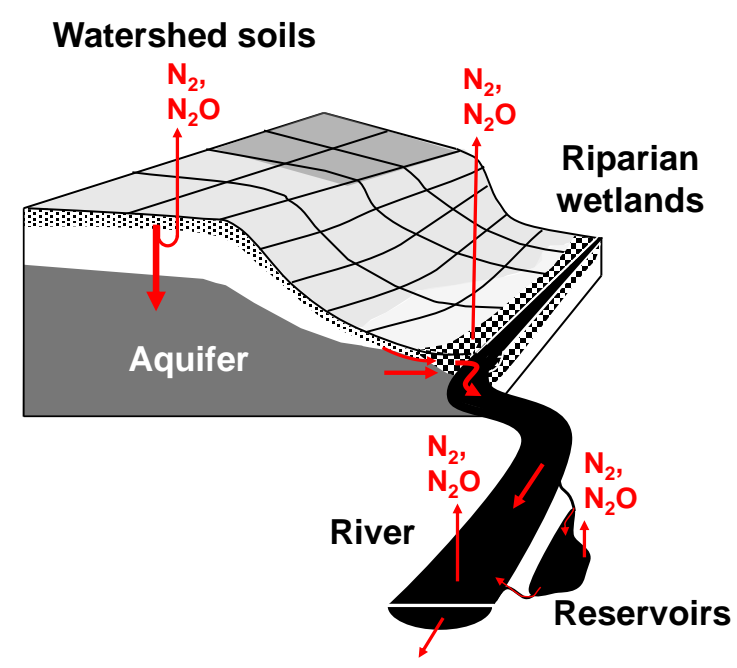

Figure 6. Block diagram showing the transfer of nitrate from watershed soils to river channel through riparian wetlands, and the associated denitrification and $\mathrm{N}_{2} \mathrm{O}$ emission. In-stream and reservoir denitrification processes are also represented.

The same holds true for in-stream denitrification processes which, although significant when expressed in terms of local per area values, affect nitrogen dynamics only marginally compared with soil and riparian processes. However, downstream from the largest point of wastewater discharge, microbial activity occurs, either heterotrophic mineralization of organic $\mathrm{N}$ into ammonium, or nitrification of ammonium, and locally affects water quality and $\mathrm{N}_{2} \mathrm{O}$ emissions (Garnier et al., 2009). In this respect, the sector of the Seine River downstream from the discharge of the Seine-Aval wastewater purification plant treating the largest part of the Paris effluents, plays a significant role. The never-ending race between an increasing $\mathrm{N}$ load collected by the sewers to the wastewater plants, and the improvement of the treatments applied is reflected in the long-term series of water quality observations and modelling results of water quality along longitudinal profiles of the lower Seine River course, as shown by Aissa-Grouz et al. (2015), Romero et al. (2016) and Garnier et al. (2019c).

Denitrification, and $\mathrm{N}_{2} \mathrm{O}$ emissions, is also significant in the large reservoirs fed by the upstream course of the Seine river and its tributaries the Aube and Marne river that were established in 1960-1990 for the purpose of discharge regulation. During the summer period of water stagnation in these reservoirs as well as in farm ponds, nitrate concentration is strongly reduced before restitution to the river network (Garnier et al., 2000; 2014; Passy et al., 2012).

\section{6. $\mathbf{N}$ delivery to the coastal zone and marine eutrophication}

The flux of $\mathrm{N}$ delivered by the Seine River at the outlet of the river network (more specifically at Poses, the entrance of the tidal estuarine sector) reflects all the diffuse and point sources distributed in the watershed area, as well as the various processes leading to the transformation, immobilization, and transfer of $\mathrm{N}$ loading along the land-water continuum (Garnier et al., 2019a). Figure 4 summarizes the long term trends of these sources and sinks and shows how the flux in $\mathrm{N}$ delivery has increased as the result of these trends. Overall, the latter currently amounts to $42-49 \%$ of net $\mathrm{N}$ sources to the watershed. $\mathrm{N}$ "retention" consists of $8 \%$ soil storage, $15 \%$ soil denitrification, $10 \%$ riparian denitrification 
and $16 \%$ in stream denitrification. The largest part of 'retention' processes thus is attributable to atmospheric emission, partly under the form of $\mathrm{N}_{2} \mathrm{O}$ contributing to climate change.

Because of the heavy morphological transformations undergone by the Seine estuary for the purpose of facilitating navigation, the $\mathrm{N}$ retention function of this system has been considerably reduced. The flux of $\mathrm{N}$ delivered to the estuary is now transferred to the Seine Bay, with only $13 \%$ (about $20 \mathrm{ktN} / \mathrm{yr}$ ) being retained on an annual basis by denitrification (Romero et al., 2018).

In the Seine Bay on the other hand, the input of nitrogen, together with the other nutrients phosphorus and silica, determine the state of eutrophication of the ecosystem. Billen and Garnier (2007b) defined the N-ICEP, an indicator of the potential role of nutrient riverine delivery in promoting the growth of undesirable, non-siliceous marine phytoplankton species in coastal bights. The concept behind this indicator is that when nutrients are brought into the sea in proportions corresponding to the Redfield ratio of algal composition, they promote the development of diatom communities able to feed a linear food chain leading to fish, while if $\mathrm{N}$ and/or phosphorus are in excess over silica with respect to diatoms requirements, algal blooms dominated by potentially toxic or harmful species develop, including dinoflagellates or even low-silicified diatoms such as Pseudo-nitzschia, producing domoïc acid in response to silica depletion (Garnier et al., 2019a). The long-term trend of the N-ICEP in the flow delivered to the Seine Bight is shown in Figure 7. While negative N-ICEP values would occur under pristine conditions, positive values have been calculated since 1850; they increased rapidly after 1950 and are still positive today, although a slow decreasing trend is observed since the 1980s. The ECOMARS-3D model of the Channel developed by IFREMER (http://wwz.ifremer.fr/mars3d/Le-modele/Descriptif/, Menesquen et al., 2018) is able to reasonably simulate diatom and nanoflagellate blooms (Passy et al., 2016; Romero et al, 2018; Desmit et al., 2018), including Pseudo-nitzschia (Garnier et al., 2019a), in response to the reconstructed riverine nutrient fluxes.

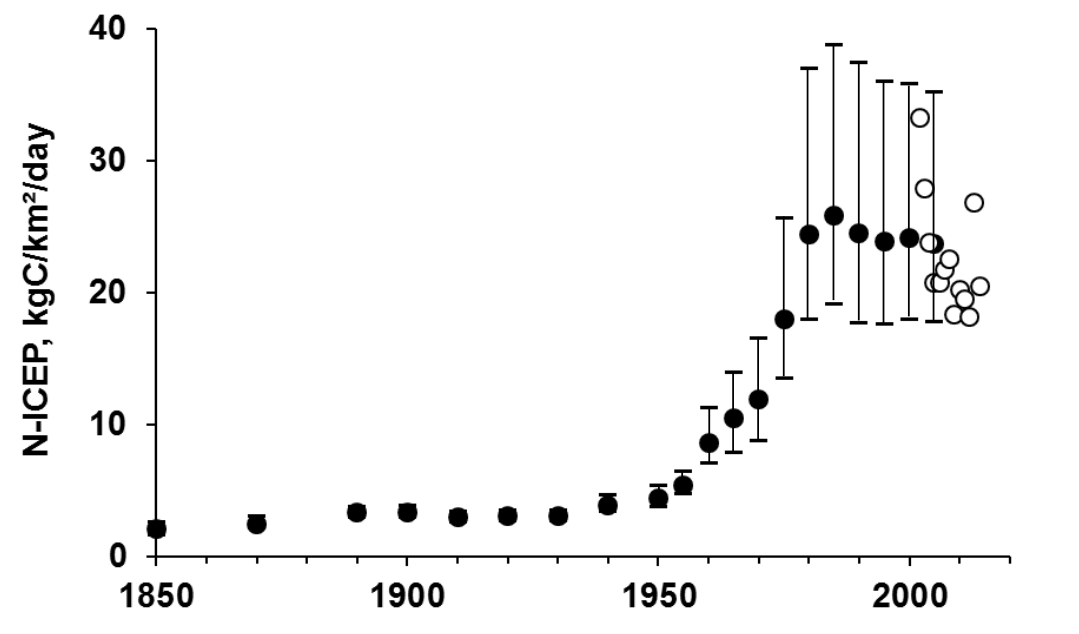

Figure 7. Long-term trends of N-ICEP in the nutrient flow delivered by the Seine River into the Seine estuarine sector (at Poses). Black circles and bars: values calculated for median, wet or dry hydrology (Billen \& Garnier, 2007b); open circles: values calculated with the Seneque-Riverstrahler model for actual conditions from 2002 and 2014 (Garnier et al., 2019a) 


\section{Two contrasting scenarios for the future}

To a large extent, the current knowledge on nutrient cycling in the past and present wateragro-food system also allows us to predict the environmental effects of possible future changes in the design of human food provision. For example, two contrasting scenarios of the future of French agro-food systems have been constructed (Billen et al., 2018a; 2019a). One of these scenarios, called "Opening and Specialization" $(\mathrm{O} / \mathrm{S})$ is constructed by extending the historical trends observed in the French agro-food system during the past few decades: livestock and permanent grasslands disappear from the central regions of the watershed but livestock farming intensifies in the peripheral regions with an increased import of soybean; cereal production for export keeps growing; a human diet rich in animal protein persists; current environmental regulations, including those related to mineral and organic $\mathrm{N}$ fertilization, are maintained.

The second scenario, called "Autonomy, Reconnection and Demitarian Diet" (A/R/D), assumes the generalization of organic farming practices with long and diversified crop rotations and no industrial fertilizers, local livestock and crop farming reconnection, and a human diet of half the current content of meat and milk. At the scale of France, both scenarios were shown to be able to meet the needs of the projected French population for 2050 , in both cases with ample exportation of cereals. In the O/S scenario France also exports animal products but imports massive amounts of feed; by contrast in the A/R/D scenario no significant net export of meat and milk occurs and no import of feed is required. At the scale of the Seine basin (which hosts $25 \%$ of the French population), the A/R/D and $\mathrm{O} / \mathrm{S}$ scenarios require importing of, respectively, $33 \%$ and $86 \%$ of animal protein requirements (Fig. 8a, Table 2 ).

Table 1 : Main functional characteristics and production fluxes of the agro-food system of the Seine watershed (in bold) and the whole of France (in italic) for the present situation (2004-2014) and for the two prospective scenarios O/S and A/R/D (Billen et al., 2018a).

\begin{tabular}{|c|c|c|c|c|}
\hline & & $\begin{array}{l}2004-2014 \\
\text { Reference }\end{array}$ & $\begin{array}{c}2050 \\
\text { Opening } \\
\text { Specialization }\end{array}$ & $\begin{array}{c}2050 \\
\text { Autonomy } \\
\text { Reconnection } \\
\text { Demitarian diet }\end{array}$ \\
\hline Population & M hab & $16(62)$ & $19(75)$ & $18(75)$ \\
\hline Vegetal protein consumption & $\mathrm{ktN} / \mathrm{yr}$ & $39(145)$ & $42(169)$ & $66(273)$ \\
\hline Animal protein consumption ${ }^{1}$ & $\mathrm{ktN} / \mathrm{yr}$ & $58(232)$ & $82(330)$ & $33(135)$ \\
\hline Agricultural area used & M ha & $4.2(28)$ & $4.1(27)$ & $4.2(28)$ \\
\hline$\%$ permanent grassland & $\%$ & $16(34)$ & $4(29)$ & $19(36)$ \\
\hline Synthetic $\mathrm{N}$ fertilizer use & $\mathrm{ktN} / \mathrm{yr}$ & $521(1955)$ & 656 (1942) & $0(0)$ \\
\hline Permanent grassland production & $\mathrm{ktN} / \mathrm{yr}$ & $96(829)$ & $35(1093)$ & $69(633)$ \\
\hline Cropland production & ktN/an & 520 (2192) & $541(2508)$ & $393(1770)$ \\
\hline Cereal Import (+) / export (-) & $\mathrm{ktN} / \mathrm{yr}$ & $-367(-540$ & $-443(-1089)$ & $-213(-222)$ \\
\hline Livestock & $\mathrm{M} \mathrm{lu}^{2}$ & $1.3(19)$ & $0.9(37)$ & $1.8(12)$ \\
\hline Meat and milk production & $\mathrm{ktN} / \mathrm{yr}$ & $18(261)$ & $11(383)$ & $21(138)$ \\
\hline Meat and milk import $(+) /$ export (-) & $\mathrm{ktN} / \mathrm{yr}$ & $40(-29)$ & $+71(-53)$ & $+11(-3)$ \\
\hline Livestock ingestion & $\mathrm{ktN} / \mathrm{yr}$ & $144(1955)$ & $91(3731)$ & $183(1224)$ \\
\hline Grazing on permanent grassland & $\%$ & $64(42)$ & $38(29)$ & $36(45)$ \\
\hline Ingestion of local crops & $\%$ & $36(35)$ & $24(26)$ & $64(55)$ \\
\hline Ingestion of imported feed & $\%$ & 0 (23) & $38(45)$ & $0(0)$ \\
\hline Feed import $(+) /$ export $(-)$ & $\mathrm{ktN} / \mathrm{yr}$ & $0(+438)$ & $+34(+1687)$ & $0(0)$ \\
\hline
\end{tabular}

${ }^{1}$ Excluding fish and seafood; ${ }^{2}$ lu : livestock unit, ruminants and monogastric animals 
Simulated water quality in the Seine drainage network shows much lower nitrate contamination in the A/R/D than in the O/S scenario (Fig. 8b), and a much lower $\mathrm{N}$ loading to the Seine Bight (respectively 3200 and $2360 \mathrm{kN} / \mathrm{km}^{2} / \mathrm{yr}$ for A/R/D and O/S, vs. $4200 \mathrm{kN} / \mathrm{km}^{2} /$ yr for 2010-2014). $\mathrm{N}_{2} \mathrm{O}$ emission from cropland soils is also considerably lower in the A/R/D than in the O/S scenario (Fig. 8c).
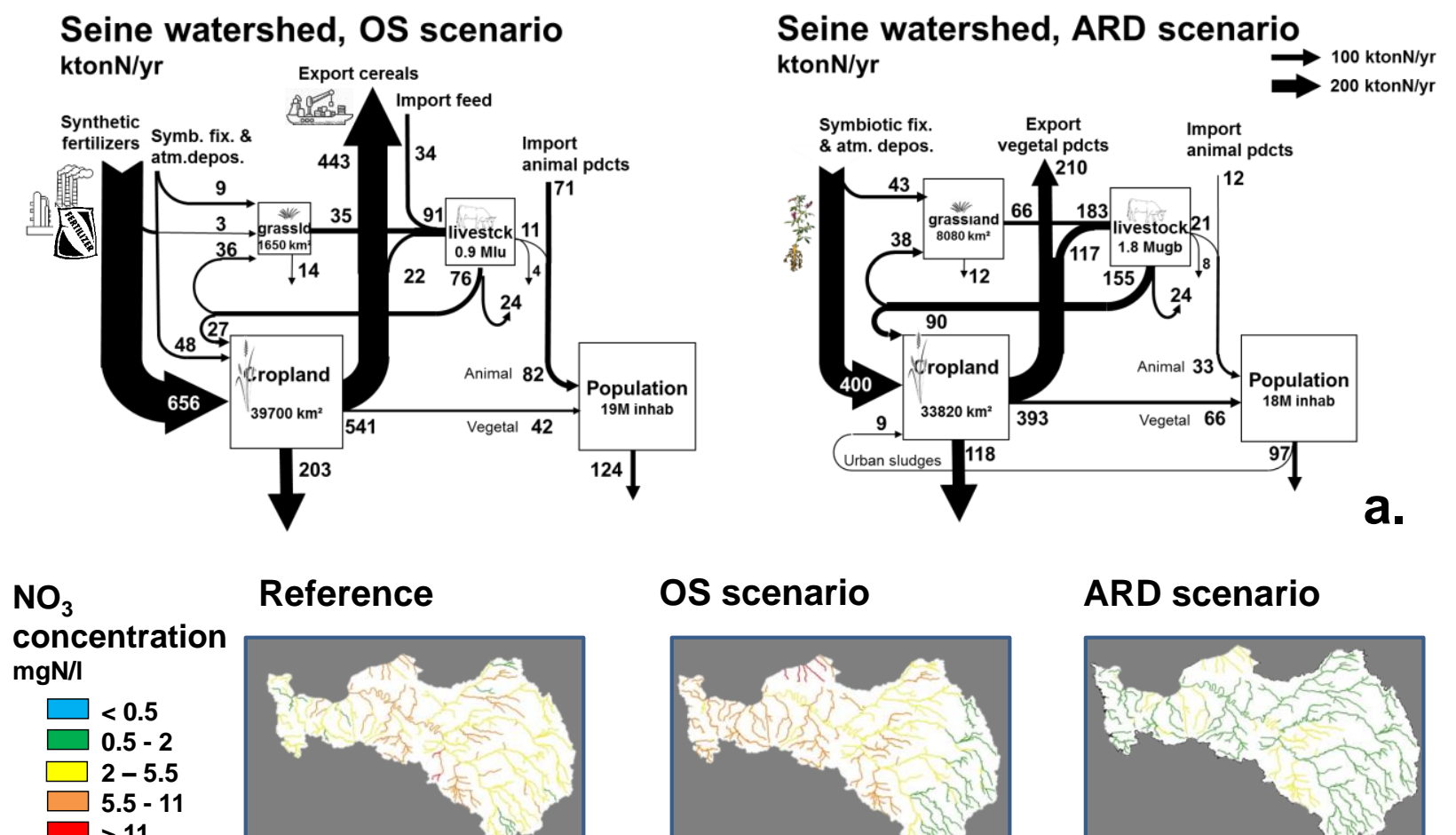

Reference

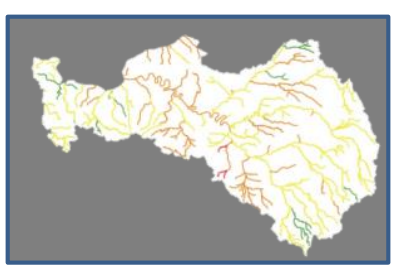

OS scenario

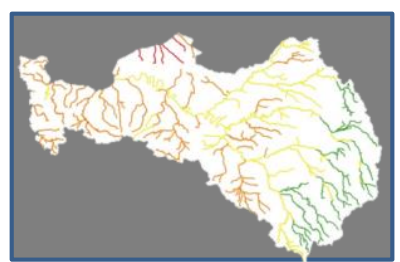

ARD scenario

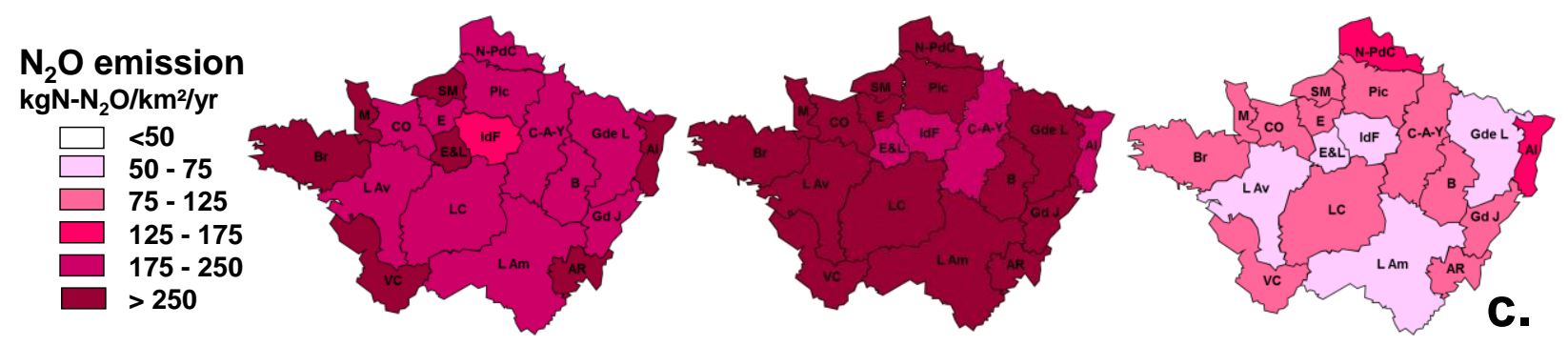

Figure 8. a. GRAFS representation of the agro-food system of the Seine watershed in the O/S and $A / R / D$ scenarios for the year 2050 (Billen et al., 2018a). b. Simulated nitrate concentration in the Seine drainage network in both scenarios compared with the present situation (calculated with the SenequeRiverstrahler model, Garnier et al., 2019a). c. calculated $\mathrm{N}_{2} \mathrm{O}$ emission by agricultural soils in both scenarios compared with the present situation (Garnier et al., 2019b)

These works underline that radical changes in the structure of the agro-food system are required to reach a good ecological status of the hydrosystem, rather than simple improvements in farming practices or policies to increase $\mathrm{N}$ use efficiency during the different transformation stages. Climate change is not taken into account in these scenarios which typically cover the next 30 years. 


\section{Conclusion}

During the past 30 years, the field of biogeochemistry, which was still in its infancy at the time the eponymous journal was founded, has evolved toward a major discipline at the core of several issues of vital importance for human life on Earth. Numerous paradigms have been formulated during this period, which today serve as the backbone of environmental sciences. The river continuum concept was extended to a full land-to-sea continuum vision; combined with the synoptic approach of agro-food systems it resulted in the water-agro-food concept that we applied here to the study of the nitrogen cascade.

The case study of the Seine basin illustrates how the knowledge gained during the past 30 years of the long term PIREN-Seine program (since 1989), on the processes involved in the $\mathrm{N}$ cycle and its perturbations, has made it possible to quantitatively describe the associated fluxes at the scale of a whole watershed, over a timespan of more than one century. Changes in land use of the watershed, and particularly in the agricultural activities and in the management of urban wastewater resulting from human nutrition are by far the main driver of the observed trajectory of the functioning of the water-agro-food system. Several possible future scenarios for the agro-food system can be constructed and their consequences estimated in terms of water quality and ecological functioning of the whole continuum of aquatic systems from rivers to the sea; their impact on the climate system through greenhouse gas emission can also be calculated. What is more challenging is to incorporate the effect of global climate change into such prospective scenarios at the regional scale. If robust estimations of the future changes in temperature, rainfall, and runoff are available for the next 30-50 years, it is feasible to incorporate these changes and calculate how they affect the control on the kinetics of the processes described in the ecosystem models. Such explorations have already been initiated with changes in hydrology but not yet with temperature (Raimonet et al., 2018; Garnier et al., 2018). A still more challenging issue is however to take into account the indirect effects of climate change on agriculture. Current cropping systems may well be severely affected by these changes, and new crops and farming practices might be introduced with consequences that are difficult to predict using our current knowledge. This issue probably remains a research priority for the coming decades.

\section{Acknowledgments}

This work was carried out within the scope of the PIREN-Seine program, supported by the Seine-Normandie Water Agency and several other partners. Several others projects are also acknowledged, especially, the NEREIS and RESET projects (GIP-Seine-Aval), as well as FLAM (Liteau \& Seine-Normandie Water Agency), ESCAPADE (ANR), HYDROGES (ADEME) and ABAC (Région lle-de-France, Seine-Normandie Water Agency and Eau de Paris). It also benefited from the scientific context of the FIRE (FR 3020), a federation for environmental research in the lle-de-France Region and of the eLTER Zone Atelier Seine, promoted by the French National Center for Scientific Research (CNRS-INEE).

\section{References}

Aissa-Grouz N, Garnier J, Billen G, Mercier B and Martinez A (2015). The response of river nitrification to changes in wastewater treatment (The case of the lower Seine River downstream from Paris). Ann. Limnol. - Int. J. Lim. 51 : 351-364. DOI: 10.1051/limn/2015031

Anglade J, Billen G, Garnier J (2015a). « La Terre » de Zola, une histoire biogéochimique de la Beauce au XIXe siècle », VertigO - la revue électronique en sciences de l'environnement [En ligne], vol 15.

http://vertigo.revues.org/16438 ; DOI : 10.4000/vertigo.16438 
Anglade J, Billen G, Makridis T, Garnier J, Puech T, Tittel C. (2015b). Nitrogen soil surface balance of organic vs conventional cash crop farming in the Seine watershed. Agricultural Systems 139:82-92.

Anglade J, Billen G, Garnier J (2017). Reconquérir la qualité de l'eau en régions de grande culture : agriculture biologique et reconnexion avec l'élevage. Fourrages. 231, 257-268. www.afpf-asso.org

Autret B, Mary B, Chenu C., Balabanec M, Girardin C, Bertrand M, Grandeau G, Beaudoin N. (2016) Alternative arable cropping systems: A key to increase soil organic carbon storage? Results from a 16 year field experiment. Agriculture, Ecosystems and Environment. 232 : 150-164.

Autret B, Mary B, Gréhan E, Ferchaud F, Grandeau G, Rakotovololona L, Bertrand M, Beaudoin N (2019) Can alternative cropping systems mitigate nitrogen losses and improve

GHG balance? Results from a 19-yr experiment in Northern France. Geoderma 342:20-33. https://doi.org/10.1016/i.geoderma.2019.01.039

Barles S (2005) L'invention des déchets urbains: France 1790-1970. Champ Vallon, Seyssel

Beaudoin N, Gallois N, Viennot P, Le Bas C, Puech T, Schott C, Mary B (2016). Evaluation of a spatialized agronomic model in predicting yield and $\mathrm{N}$ leaching at the scale of the Seine-Normandie basin. Environmental Science and Pollution Research. DOI 10.1007/s11356-016-7478-3.

Beaulieu JJ, Tank JL, Hamilton SK, Wollheim WM, Hall Jr RO, Mulholland PJ, Peterson BJ, Ashkenas LR, Cooper LW, Dahm CN, Dodds WK, Grimm NB, Johnson SL, McDowell WH, Poole GC, Valett HM, Arango CP, Bernot MJ, Burgin J, Crenshaw CL, Helton AM, Johnson LT, O'Brien JM, Potter JD, Sheibley RW, Sobota DJ and Thomas SM (2011). Nitrous oxide emission from denitrification in stream and river networks. PNAS 108: 214-219. doi/10.1073/pnas.1011464108

Benoit M, Garnier J, Billen G (2014). Nitrous oxide production from nitrification and denitrification in agricultural soils: determination of temperature relationships in batch experiments Processes in Biochem.

DOI: 10.1016/j.procbio.2014.10.013

Benoit M, Garnier J, Beaudoin N, Billen G (2016) A network of organic and conventional crop farms in the Seine Basin (France) for evaluating environmental performance: yield and nitrate leaching. Agricultural Systems, 148: 105-113. http://dx.doi.org/10.1016/i.agsy.2016.07.005

Berthier L, Bardy M, Chenu JP, Guzmova L, Laroche B, Lehmann S, Lemercier B, Martin M, Mérot P, Squividant $\mathrm{H}$, Thiry $\mathrm{E}$, Walter $\mathrm{C}$ (2014). Enveloppes des milieux potentiellement humides de la France me'tropolitaine. Notice d'accompagnement. Programme de modélisation des milieux potentiellement humides de France, Ministère d'Ecologie, du Développement Durable et de l'Energie. http://geowww.agrocampus-ouest.fr/web/?p=1538

Billen G, Garnier J, Nemery J, Sebilo M, Sferratore A, Benoit P, Barles S, Benoit M (2007a) A long term view of nutrient transfers through the Seine river continuum. The Science of the Total Environment 275: 80-97

Billen G, Garnier J (2007b). River basin nutrient delivery to the coastal sea: assessing its potential to sustain new production of non siliceous algae. Marine Chemistry. 106: 148-160

Billen G, Barles S, Chatzimpiros P, Garnier J (2012a). Grain, meat and vegetables to feed Paris: where did and do they come from? Localising Paris food supply areas from the eighteenth to the twenty-first century. Regional Environmental Change. $12: 325-336$.

Billen G, Garnier J, Silvestre M, Thieu V, Barles S, Chatzimpiros P (2012b). Localising the nitrogen imprint of Paris food supply: the potential of organic farming and changes in human diet. Biogeosciences 9, 607-616.

Billen G, Le Noë J, Garnier J. (2018a). Two contrasted future scenarios for the French agro-food system. Science of the Total Environment. 637-638: 695-705. Doi: 10.1016/j.scitotenv.2018.05.043

Billen G, Ramarson A, Thieu V, Théry S, Silvestre M, Pasquier C, Hénault C, Garnier J. (2018b) Nitrate retention at the river-watershed interface: a new conceptual modeling approach. Biogeochemistry 139:31-51. DOI : $10.1007 / \mathrm{s} 10533-018-0455-9$

Billen G, Le Noë J, Anglade J, Garnier J.(2019a). Polyculture-élevage ou hyper-spécialisation territoriale? Deux scénarios prospectifs du système agro-alimentaire français Innovations Agronomiques 72 (2019), 31-44

Billen G, Garnier J, Le Noë J, Viennot P, Gallois N, Puech T, Schott C, Anglade J, Mary B, Beaudoin N, Léonard J, Mignolet C, Théry S, Thieu T, Silvestre M, and Passy P. (2019b). The Seine Watershed Water-Agro-Food 
System: Long-Term Trajectories of C, N and P Metabolism In Flipo N, Labadie P and Lestel L (eds.), The Seine River Basin, Handbook of Environmental Chemistry. Doi 101007/698_2019_393

Billen G, Garnier J, Grossel A, Thieu V, Théry S, Hénault C. (2020). Modeling indirect N2O emissions along the N cascade from cropland soils to rivers. Biogeochemistry $148: 207-221$. https://doi.org/10.1007/s10533-020$\underline{00654-x}$

Butterbach-Bahl K, Baggs EM, Dannenmann M, Kiese R and Zechmeister-Boltenstern S. (2013). Nitrous oxide emissions from soils: how well do we understand the processes and their controls? Phil Trans Roy Soc B 368: 20130122. 368: 20130122. doi.org/10.1098/rstb.2013.0122

Constantin J, Mary B, Laurent F, Aubrion G, Fontaine A, Kerveillant P, Beaudoin N (2010) Effects of catch crops, no till and reduced nitrogen fertilization on nitrogen leaching and balance in three long-term experiments. Agric Ecosyst Environ 135:268-278

Desmit X, Thieu V, Dulière V, Ménesguen A, Campuzano F, Lassaletta L, Sobrinho JL, Silvestre M, Garnier J, Neves R, Billen G, Lacroix G (2018). Reducing marine eutrophication may require a paradigmatic change. Science of the Total Environment. 635: 1444-1466. doi.org/10.1016/j.scitotenv.2018.04.1

Esculier F, Le Noë J, Barles S, Billen G, Créno B, Garnier J, Lesavre J, Petit L, Tabuchi J-P (2018). The biogeochemical imprint of human metabolism in Paris Megacity: a regionalized analysis of a water-agro-food system. J. Hydrol. DOI 10.1016/j.jhydrol.2018.02.043

Esculier F., Barles S. (2019) Past and Future Trajectories of Human Excreta Management Systems: Paris in the Nineteenth to Twenty-First Centuries. In: The Handbook of Environmental Chemistry. Springer. doi.org/10.1007/698_2019_407

Galloway JN, John D. Aber JD, Jan Willem Erisman JW, Sybil P. Seitzinger SP, Robert W. Howarth RW, Ellis B. Cowling EB, B. Jack Cosby J,(2003). The Nitrogen Cascade, BioScience, 53: 341-356.

https://doi.org/10.1641/0006-3568

Galloway JN, Dentener FJ, Capone DG, Boyer EW, Howarth RW, Seitzinger SP, Asner GP, Cleveland CC, Green PA, Holland EA, Karl DM, Michaels AF, Porter JH, Townsend AR, and Vorosmarty CL (2004). Nitrogen cycles: past, present, and future. Biogeochemistry 70: 153-226.

Garnier J, Billen G, Sanchez N, Leporcq B (2000). Ecological functioning of a large reservoir in the upstream basin of the river Seine (Marne reservoir, France). Regulated Rivers, Research and Management. 16:51-71.

Garnier J, Billen G, Vilain G, Martinez A, Mounier E, Silvestre M, Toche F (2009). Nitrous oxide (N2O) in the Seine river and basin: observations and budgets. Agric. Ecosyst. Environ. $133: 223-233$. doi:10.1016/j.agee.2009.04.024.

Garnier J, Billen G, Vilain G, Benoit M, Passy P, Tallec G, Tournebize J, Anglade J, Billy C, Mercier B, Ansart P, Sebilo M, Kao C (2014). Curative vs. preventive management of nitrogen transfers in rural areas: lessons from the case of the Orgeval watershed (Seine River basin, France). J. Environmental Management. 144 : 125-134. DOI 10.1016/j.jenvman.2014.04.030

Garnier J, Lassaletta L, Billen G, Romero E, Grizzetti B, Némery J, Le QLP, Pistocchi C, Aissa-Grouz N, Luu MTN, Vilmin L, Dorioz J-M (2015). Phosphorus budget in the water-agro-food system at nested scales in two contrasted regions of the world (ASEAN-8 and EU-27). Global Biog. Cycle. 10.1002/2015GB005147.

Garnier J, Ramarson A, Billen G, Théry S, Thiéry D, Thieu V, Minaudo C, Moatar F (2018). Nutrient inputs and hydrology together determine biogeochemical status of the Loire River (France): current situation and possible future scenarios. Science of the Total Environment, 637-638: 609-624. doi.org/10.1016/j.scitotenv.2018.05.045 Garnier J, Billen G., Legendre R., Riou Ph., Cugier Ph., Schapira M., Théry S., Thieu V., Menesguen A. (2019a). Managing the Agri-Food System of Watersheds to Combat Coastal Eutrophication: A Land-to-Sea Modelling Approach to the French Coastal English Channel. Geosciences. 9, 441; doi:10.3390/geosciences9100441

Garnier J, Le Noë J, Marescaux A, Sanz-Cobena A, Lassaletta L, Silvestre M, Thieu V, Billen G. (2019b). Longterm changes in greenhouse gas emissions from French agriculture and livestock (1852-2014): from traditional agriculture to conventional intensive systems. Science of the Total Environment. 660: 1486-1501. doi.org/10.1016/j.scitotenv.2019.01.048.

Garnier J, Marescaux A, Guillon S, Vilmin L, Rocher V, Billen G, Thieu V, Silvestre M, Passy P, Groleau A, Tallec G, Flipo N (2019c). Ecological functioning of the Seine River: from long-term modelling approaches to highfrequency data analysis. In: Flipo N, Labadie P, Lestel L (2020). The Seine River basin, Handbook of Environmental Chemistry, Springer. DOI 10.1007/698_2019_379. 
Gruber N, Galloway JN (2008). An Earth-system perspective of the global nitrogen cycle. Nature.451: 17 .doi:10.1038/nature06592

Hénault C, Bizouard F, Laville P, Gabrielle B, Nicoullaud B, Germon JC, Cellier P. (2005). Predicting in situ soil N2O emission using NOE algorithm and soil database. Global Change Biology (2005) 11, 115-127, doi: 10.1111/j.1365-2486.2004.00879.x

Hénault C., Bourennane H, Ayzac A, Ratié C, Saby NPA, Cohan J-P, Eglin T, Le Gall C. (2019). Management of soil pH promotes nitrous oxide reduction and thus mitigates soil emissions of this greenhouse gas. Sci Rep 9, 20182. https://doi.org/10.1038/s41598-019-56694-3

Justes E, Beaudoin N, Bertuzzi P, Charles R, Constantin J, Dürr C, Hermon C, Joannon A, Le Bas C, Mary B, Mignolet C, Montfort F, Ruiz L, Sarthou JP, Souchère V, Tournebize J (2012). Réduire les fuites de nitrate au moyen de cultures intermédiaires

Conséquences sur les bilans d'eau et d'azote, autres services écosystémiques. Rapport d'étude. INRA.

Délégation à l'expertise scientifique, à la prospective et aux études.

https://www6.paris.inrae.fr/depe/content/download/3183/32222/version/2/file/

Kampschreur MJ, Temmink H, Kleerebezem R, Jetten MS, van Loosdrecht M., CM (2009). Nitrous oxide emission during wastewater treatment, Water Research, doi: 10.1016/j.watres.2009.03.001

Knowles R (1982) Denitrification. Microbiol Rev 46(1):43

Lassaletta L, Billen G, Grizzetti B, Anglade J, Garnier J (2014). 50 year trends in nitrogen use efficiency of world cropping systems: the relationship between yield and nitrogen input to cropland. Environ. Res. Lett. 9.

DOI:10.1088/1748-9326/9/10/105011

Ledoux E, Gomez E, Monget JM, Viavatene C, Viennot P, Ducharne A, Benoit M, Mignolet C, Schott C, Mary B. (2007). Agricultre and groundwater nitrate contamination in the Seine basin. The STICS-MODCOU modeling chain. Science of the Total Environment, 375: 33-47.

Le Noë J, Billen G, Garnier J (2017). How the structure of agro-food systems shapes nitrogen, phosphorus, and carbon fluxes: the Generalized Representation of Agro-Food System applied the regional scale in France. Science of the Total Environment 586: 42-55. http://dx.doi.org/10.1016/j.scitotenv.2017.02.040

Le Noë J, Billen G, Esculier F, Garnier J. (2018) Long-term socioecological trajectories of agro-food systems revealed by $\mathrm{N}$ and $\mathrm{P}$ flows in French regions from 1852 to 2014. Agr Ecosyst Env. 265: 132-143. https://doi.org/10.1016/j.jenvman.2017.09.039

Le Noë J, Billen G, Garnier J (2019a). Carbon dioxide emission and soil sequestration for the French agro-food system: present and prospective scenarios. Frontiers in Sustainability. DOI: 10.3389/FSUFS.2019.00019.

Le Noë J, Billen G, Mary B, Garnier J (2019b). Drivers of long-term carbon dynamics in cropland: a bio-political history (France, 1852-2014). Environmental Science and Policy. 93: 53-65. doi.org/10.1016/j.envsci.2018.12.027

Le Noë J, Erb KH, Matej S, Magerl A, Bhan M, Gingrich S. (2020). Carbon stock shifts in the land-use sector is a side-effect of changes in the socio-ecological metabolism: empirical evidences for the case of France (18502015). Anthropocene

Lotka AJ (1924). Elements of physical biology. Williams \& Wilkins Co, Inc.

Ménesguen A, Dussauze M, Dumas F, Thouvenin B, Garnier V, Lecornu F, Répécaud M (2018). Ecological model of the Bay of Biscay and English Channel shelf for environmental status assessment part 1: Nutrients, phytoplankton and oxygen. Ocean Modelling 133, 56-78.

Mignolet C, Schott C., Benoit M (2007). Spatial dynamics of farming practices in the Seine basin : Methods for agronomic approaches on a regional scale. Science of the Total Environment, 375 (1-3), 13-32. , DOI : 10.1016/j.scitotenv.2006.12.004

Passy P, Garnier J, Billen G, Fesneau C, Tournebize J. (2012). Restoration of ponds in rural landscapes: Modelling the effect on nitrate contamination of surface water (the Seine River Basin, France). Science of the Total Environment 430: 280-290. doi:10.1016/j.scitotenv.2012.04.035

Passy P, Le Gendre R, Garnier J, Cugier P, Callens J, Paris F, Billen G., Riou P, Romero E (2016). Eutrophication modelling chain for improved management strategies to prevent algal blooms in the Seine Bight. Mar. Ecol. Prog. Ser. 543:107-125. doi: http://dx.doi.org/10.3354/meps11533. 
Raimonet M, Thieu V, Silvestre M, Oudin L, Rabouille C, Vautard R, Garnier J (2018). Coastal eutrophication potential under future climate change: a landward perspective. Frontiers in Marine Science, section Marine Biogeochemistry, 5, 136. doi: 10.3389/fmars.2018.00136

Rakotovololona L, Beaudoin N, Ronceux A, Venet E, Mary B (2018) Driving factors of nitrate leaching in arable organic cropping systems in Northern France. Agric Ecosyst Environ 272:38-51

Rochester I J (2003) Estimating nitrous oxide emissions from flood-irrigated alkaline grey clays. Australian Journal of Soil Research, 41: 197-206

Romero E, Le Gendre R, Garnier J, Billen G, Fisson C, Silvestre M, Riou Ph (2016). Long-term water quality in the lower Seine: lessons learned over 4 decades of monitoring. Environmental Science and Policy, 58: 141-154. doi.org/10.1016/j.envsci.2016.01.016.

Romero E, Garnier J, Billen G, Ramarson A, Riou P, Le Gendre R (2018). Modeling the biogeochemical functioning of the Seine estuary and its coastal zone: Export, retention, and transformations. Limnology and Oceanography doi: 10.1002/Ino.11082

Schlesinger WH (2009) On the fate of anthropogenic nitrogen. Proc. National Acad. Sci 106: 203-208

Simek M, Cooper JE (2002a) The influence of soil pH on denitrification:progress towards the understanding of this interaction over the last 50 years. European Journal of Soil Science. 53,345-354

Simek M, Jisova L, Hopkins DW (2002b). What is the so-called pH-optimum of denitrification? Soil Biology and Biogeochemistry 34:1227-1234.

Smil V (1999) Nitrogen in crop production: An account of global flows. Global Biogeochemical Cycles. 13:647662.

Sutton MA, Howard CM, Erisman JW, Billen G, Bleeker A, Grennfelt P, van Grinsven H, Grizzetti B (2011). The European Nitrogen Assessment: sources, effects and policy perspectives. Cambridge University press. 612 pp.

Tiedje JM, Sexstone AJ, Myrold DD, Robinson JA (1982). Denitrification: ecological niches, competition and survival. Antonie van Leeuwenhoek J. Microbiol. 48:569-583

Vannote RL, Minshall GW, Cummins KW, et al (1980) The River Continuum Concept. Can J Fish Aquat Sci 37:130-137. https://doi.org/10.1139/f80-017

Vergnaud-Ayraud V, Aquilina L, Pauwels H, Labasque T (2008). La datation des eaux souterraines par analyse des CFC : un outil de gestion durable de la ressource en eau. Tech. Sci. Méthodes 37-44. doi: $10.1051 / \mathrm{tsm} / 200801037$

Vilain G, Garnier J, Decuq C, Lugnot M (2014). Nitrous oxide production by nitrification vs. denitrification in experimental conditions. Nutr Cycl Agroecosyst, 98, 169-186. DOI 10.1007/s10705-014-9604-2

Ward J V (1989) The Four-Dimensional Nature of Lotic Ecosystems. J North Am Benthol Soc 8:2-8

Weier KL, Doran JW, Power JF, Walters DT (1993) Denitrification and the dinitrogen nitrous-oxide ratio as affected by soil-water, available carbon, and nitrate. Soil Sci Soc Am J 571:66-72

Willett W, Rockström J, Loken B, Springmann M, Lang T, Vermeulen S, Garnett T, Tilman D, DeClerck F, Wood A, Jonell M, Clark M, J Gordon LJ, Fanzo J, Hawkes C, Zurayk R, Rivera JA, De Vries W, Majele Sibanda L, Afshin A, Chaudhary A, Herrero M, Agustina R, Branca F, Lartey A, Fan S, Crona B, Fox E, Bignet V, Troell M, Lindahl T, Singh S, Cornell SE, K Srinath Reddy K, Narain S, Nishtar S, Murray CJL (2019). Food in the Anthropocene: the EAT-Lancet Commission on healthy diets from sustainable food systems. The Lancet. http://dx.doi.org/10.1016/S0140-6736(18)31788-4 